East European Journal of Physics

East Eur. J. Phys. 1. 121-136(2020)

DOI: $10.26565 / 2312-4334-2020-1-11$

PACS: 89.65.Gh

\title{
HYDRODYNAMIC MODEL OF TRANSPORT SYSTEM
}

\author{
(D) Oleh M. Pihnastyi ${ }^{a *,}$, DValery D. Khodusov ${ }^{b * *}$ \\ ${ }^{a}$ National Technical University "KhPI" \\ Kyrpychev str. 2, Kharkiv, Ukraine \\ ${ }^{b}$ V.N. Karazin Kharkiv National University, Kharkov, Ukraine \\ *Corresponding Author: pihnastyi@gmail.com,**vkodusov@ukr.net \\ Received December 18, 2019; revised January 20, 2020; accepted January 22, 2020
}

\begin{abstract}
A hydrodynamic model of production systems with a flow method of organizing production is considered. The basic macroparameters of the state of the production flow line and the relationship between them are determined. The choice of a lot of moment approximation for modelling the production line is justified. It is shown that the conveyor-type flow line is a complex dynamic system with distributed parameters. The boundary value problem is formulated for the longitudinal vibrations of the conveyor belt when the material moves along the transportation route. It is assumed that there is no sliding of material along the conveyor belt, and the deformation that occurs in the conveyor belt is proportional to the applied force (Hooke's elastic deformation model). The significant effect of the uneven distribution of the material along the transportation route on the propagation velocity of dynamic stresses in the conveyor belt is shown. When constructing the boundary and initial conditions, the recommendations of DIN 22101 : 2002-08 were used. The mechanism of the occurrence of longitudinal vibrations of the conveyor belt when the material moves along the transportation route is investigated. The main parameters of the model that cause dynamic stresses are determined. It is shown that dynamic stresses are formed as a result of a superposition of stresses in the direct and reflected waves. Analytical expressions are written that make it possible to calculate the magnitude of dynamic stresses in a conveyor belt and determine the conditions for the occurrence of destruction of the conveyor belt. The characteristic phases of the initial movement of the material along the technological route are considered. The process of the emergence of dynamic stresses with the constant and variable acceleration of the conveyor belt is investigated. The dynamics of stress distribution along the transportation route is presented. It is shown that the value of dynamic stresses can exceed the maximum permissible value, which leads to the destruction of the conveyor belt or structural elements. The transition period is estimated, which is required to ensure a trouble-free mode of transport operation during acceleration or braking of the conveyor belt. The use of dimensionless parameters allows us to formulate criteria for the similarity of conveyor systems.
\end{abstract}

KEY WORDS: hydrodynamic model of a transport system, two-moment description, Hooke model, balance equations, PDE production model

The methods of statistical physics are one of the tools for modelling production systems with the flow method of organizing production [1], [2]. The developed models of production systems in the hydrodynamic approximation are widely used in the design of highly efficient flow production line control systems at leading world enterprises [3]. The values of the macro parameters of the state of the production system are determined through the values of the state parameters of a large number of products that are in different stages of processing in technological operations along the technological route [4]. The main macro-parameters of the state used to describe production systems with the in-line method of organizing production are the density of products in inter operational backlogs $[\chi]_{0}(t, S)$ and the intensity of product processing $[\chi]_{1}(t, S)$ for technological operations. The trajectories of the movement of individual products along the technological route are determined by the laws established by the technological process of manufacturing the finished product and are reflected in the route maps of the enterprise. As a result of technological processing, the product passes from one state to another as a result of exposure to technological equipment and the interaction between individual products $[1,4]$. The set of points that specify a continuous change in the state of the product determines the technological path of the product in the phase state space. The change in the condition of the product as a result of the influence of technological equipment occurs as a result of the transfer of technological resources to products. The balance equations for the macroscopic parameters of the production system with the flow type of organization of production are determined, to a large extent, by the technological laws of the interaction of products with each other and technological equipment.

\section{DISTRIBUTED MODEL OF THE PRODUCTION LINE}

In a multi-moment approximation, the system of balance equations for the macro parameters of the production flow line has the form [1-3]:

$$
\frac{\partial[\chi]_{0}(t, S)}{\partial t}+\frac{\partial[\chi]_{1}(t, S)}{\partial S}=\int_{0}^{\infty} G(t, S, \mu) d \mu
$$




$$
\begin{gathered}
\frac{\partial[\chi]_{k}(t, S)}{\partial t}+\frac{\partial[\chi]_{k+1}(t, S)}{\partial S}+k f(t, S)[\chi]_{k-1}(t, S)=\int_{0}^{\infty} \mu^{k} G(t, S, \mu) d \mu, \\
\int_{0}^{\infty} \mu^{k} \chi(t, S, \mu) d \mu=[\chi]_{k}(t, S), \quad k \geq 0, \quad f(t, S)=\frac{\partial}{\partial t}\left(\frac{[\chi]_{1 \psi}(t, S)}{[\chi]_{0}(t, S)}\right)+\frac{[\chi]_{l \psi}(t, S)}{[\chi]_{0}(t, S)} \frac{\partial}{\partial S}\left(\frac{[\chi]_{1 \psi}(t, S)}{[\chi]_{0}(t, S)}\right),
\end{gathered}
$$

where $S$ is the technological position at which the product is in the technological route at a time $t$ (waiting for processing or processing), $S \in\left[0, S_{d}\right] ; \chi(t, S, \mu)$ is function of the distribution of subjects of labour by state in the phase technological space; $[\chi]_{1 \psi}(t, S)$ is the rate of processing products along the technological route at the position determined by the coordinate $S$ (the processing rate of the product in accordance with the technical documentation or equipment data sheet). The pace of processing products $[\chi]_{1 \psi}(t, S)$ in most cases is considered a given. $G(t, S, \mu)$ is a function that determines the process of equipment transferring technological resources to the subject of labour [1]. The system of equations (1) is not closed. Closing conditions are determined from the specific operating conditions of the production line. To describe the state of a production system with a flow method of organizing production, in the vast majority of cases, the first two moments $[\chi]_{0}(t, S)$ or $[\chi]_{1}(t, S)$ of the distribution function of subjects of labour by the states $\chi(t, S, \mu)$ are used. When constructing models in the one-moment description, the closure condition is often applied:

$$
\frac{\partial[\chi]_{0}(t, S)}{\partial t}+\frac{\partial[\chi]_{1}(t, S)}{\partial S}=0, \quad[\chi]_{1}(t, S)=[\chi]_{1 \psi}(t, S) .
$$

The disadvantage of the one-moment description is that such a description does not provide an opportunity to study the fluctuations of the flow parameters of the production line. To describe production lines for which the presence of fluctuations in flow parameters is of practical importance, a two-moment description can be used:

$$
\begin{gathered}
\frac{\partial[\chi]_{0}(t, S)}{\partial t}+\frac{\partial[\chi]_{1}(t, S)}{\partial S}=\int_{0}^{\infty} G(t, S, \mu) d \mu, \quad \frac{\partial[\chi]_{1}(t, S)}{\partial t}+\frac{\partial[\chi]_{2}(t, S)}{\partial S}+f(t, S)[\chi]_{0}(t, S)=\int_{0}^{\infty} \mu G(t, S, \mu) d \mu \\
{[\chi]_{2}=\int_{0}^{\infty} \mu^{2} \chi(t, S, \mu) d \mu=[\chi]_{1}(t, S) \frac{[\chi]_{1}(t, S)}{[\chi]_{0}(t, S)}+\int_{0}^{\infty}\left(\mu-\frac{[\chi]_{1}(t, S)}{[\chi]_{0}(t, S)}\right)^{2} \chi(t, S, \mu) d \mu .}
\end{gathered}
$$

Such systems may include conveyor-type production lines, for which fluctuations in flow parameters exceeding the limit level can lead to break down of technological equipment. As an alternative approach for studying fluctuations in the flow parameters of production lines, kinetic models of production lines can be called [5]. However, kinetic models are currently not widely used for designing highly efficient production line control systems. In this regard, the main focus of this article will be on the study of fluctuations in the flow parameters of the production line using a twomoment model in the form (2).

\section{CONVEYOR TYPE PRODUCTION LINE MODEL}

Among the models of conveyor systems, two large groups should be distinguished. The first group includes models for calculating the flow parameters of the conveyor line. When building models of this group are used: the finite element method (FEM) [6]; finite difference method (FDM) [7]; Lagrange equations [8]; aggregated equation of state $[9,10,11]$; equations for neural network layers [12]; system dynamics equations [13] and multiple regression equations [14-16]. The models of the first group are used in the tasks of operational planning of production activities of the enterprise. For a given quality criterion, the algorithms of optimal control of the flow parameters of the transport system are built on the foundation of these models. The second group includes models for the force calculation of structural elements of the transport system [16-22]. Of particular practical interest are the models that determine the conditions for the destruction of the conveyor belt [6,8,23-29]. This allows you to determine the design parameters of the conveyor belt and the dynamic load modes, which ensure the stable operation of the transport system. The energy consumption required for the transport system (belt conveyor type $2 \mathrm{LU} 120 \mathrm{~V}$ ) can be represented by the expression [30-32]:

$$
N(t)=N_{x x}+n_{1} M(t)
$$

where $N_{x x}$ is the power of the conveyor idling; $n_{1}$ is increment of power consumption with an increase in the mass of cargo on the conveyor by 1 ton. According to the experiment for a belt conveyor type $2 \mathrm{LU} 120 \mathrm{~V} N_{x x}=160(\mathrm{~kW})$, $n_{1}=1,11(\mathrm{~kW} / \mathrm{t})$. The theoretical calculation of the standard energy costs required for the operation of the $2 \mathrm{LU} 120 \mathrm{~V}$ 
conveyor line [31, p.62] of length $S_{d}=730(\mathrm{~m})$, with an average belt speed $a(t)=3.15(\mathrm{~m} / \mathrm{sec})$, maximum productivity $[\chi]_{1}(t, 0)=1450(t / h)$ and mass per linear meter of moving parts $[\chi]_{0 C}=138.1(\mathrm{~kg} / \mathrm{m})$ in the normative loading mode gives the following values model coefficients: $N_{x x}=123.84(\mathrm{~kW}), \mathrm{n}_{1}=1.23(\mathrm{~kW} / \mathrm{t})$. The maximum amount of material in the transport system with a uniform distribution of material on the conveyor belt is $M_{\max } \approx 100(t)$ for the maximum allowable linear density $[\chi]_{0 \max } \approx 134(\mathrm{~kg} / \mathrm{m})$ :

$$
M_{\max }=\frac{[\chi]_{1}(t, 0)}{a(t)} S_{d}=\frac{1450(t / h)}{3.15(\mathrm{~m} / \mathrm{sec})} 730(\mathrm{~m}) \approx 100(t), \quad[\chi]_{0 \max }=\frac{M_{\max }}{S_{d}} \approx \frac{100(t)}{730(\mathrm{~m})} \approx 134(\mathrm{~kg} / \mathrm{m}) .
$$

Experimental studies and theoretical calculations show that the maximum allowable linear density $[\chi]_{0 \max }$ and mass per linear meter of moving parts $[\chi]_{0 C}$ are comparable quantities. The unit cost of energy for the movement of the material of a unit mass can be represented in the following form

$$
\frac{N(t)}{M(t)}=\frac{N_{x x}}{M(t)}+n_{1}=n_{x x} \frac{[\chi]_{0 C}}{[\chi]_{0}}+n_{1},
$$

where $n_{x x}$ is unit costs of electricity for moving a running meter of conveyor belt. Expression (4) demonstrates two ways to reduce the unit cost of energy. The first way is to reduce the weight of a running meter of moving parts $[\chi]_{0 C}$, in particular, by changing the thickness of the cross section of the conveyor belt. The second way is to increase the load on conveyor systems $[\chi]_{0} \rightarrow[\chi]_{0 \text { max }}$ when applying algorithms to control the speed of conveyor belts $[25,32,33]$, which makes it possible to save up to $30 \%$ in the specific energy spent on moving the material $[25,30]$. As a result of using conveyor belt speed control systems, a 30\% reduction in specific energy costs is achieved by increasing the load on conveyor systems, for which the traditional filling level of conveyor belt material is $60-100 \%$. However, as a result of controlling the speed of the belt, there is a constant acceleration and braking of the conveyor belt loaded with material. This causes additional stresses on the material of the conveyor belt and, as a result, its damage. One of the ways to avoid damage to the conveyor belt is to increase the thickness of the conveyor belt, and therefore the mass of a running meter of moving parts $[\chi]_{0 C}$. An increase in the mass of a running meter of the conveyor belt leads to an increase in the specific energy costs required to move the extracted material of a single mass. In this regard, in the present work, the main attention is paid to the interconnection of the stream parameters of the conveyor and the design parameters of the conveyor belt.

To build a model of the transport system, we use the two-moment description equations (2) in the following form [35]:

$$
\frac{\partial[\chi]_{0}(t, S)}{\partial t}+\frac{\partial[\chi]_{1}(t, S)}{\partial S}=\delta(S) \lambda(t), \quad \frac{\partial[\chi]_{1}(t, S)}{\partial t}+\frac{\partial[\chi]_{2}(t, S)}{\partial S}-f(t, S)[\chi]_{0}(t, S)=\delta(S) \lambda(t) \frac{[\chi]_{1}(t, S)}{[\chi]_{0}(t, S)} .
$$

The system of equations (5) corresponds to the case when the material does not crumble during transportation along the technological route. We will also assume that the material does not spread along the technological route:

$$
\int_{0}^{\infty}\left(\mu-\frac{[\chi]_{1}(t, S)}{[\chi]_{0}(t, S)}\right)^{2} \chi(t, S, \mu) d \mu=P(t, S), \quad[\chi]_{2}=[\chi]_{1}(t, S) \frac{[\chi]_{1}(t, S)}{[\chi]_{0}(t, S)} .
$$

We introduce the notation for the speed of the belt in the equilibrium $\mu_{\psi}$ and nonequilibrium state $\langle\mu\rangle$ [35]:

$$
\langle\mu\rangle=\frac{[\chi]_{1}(t, S)}{[\chi]_{0}(t, S)} .
$$

Taking into account (6), we multiply the first equation (5) by $\left([\chi]_{1}(t, S) /[\chi]_{0}(t, S)\right)$ and subtract the result from the second equation (5), we obtain a system of equations for a two-moment description of the transport system:

$$
\frac{\partial[\chi]_{0}(t, S)}{\partial t}+\frac{\partial[\chi]_{1}(t, S)}{\partial S}=\delta(S) \lambda(t), \quad[\chi]_{0}(t, S) \frac{\partial\langle\mu\rangle}{\partial t}+[\chi]_{1}(t, S) \frac{\partial\langle\mu\rangle}{\partial S}=[\chi]_{0}(t, S) f(t, S)-\frac{\partial P(t, S)}{\partial S} .
$$


For a conveyor line, the force moving the material acts on the element of the conveyor belt and can be represented in the form (Fig. 1):

$$
\begin{aligned}
& d m \frac{d\langle\mu\rangle}{d t}=R(t, S+d S)-R(t, S)-d F_{W}, \quad d m=\left([\chi]_{0}(t, S)+[\chi]_{0 C}\right) d S, \\
& R(t, S+d S)=\sigma(t, S+d S) B h, \quad R(S)=\sigma(t, S) B h, \quad R(t, S+d S)-R(t, S) \approx \frac{\partial R(t, S)}{\partial S} d S,
\end{aligned}
$$

where $d m$ is total mass acting on the belt; $B$ is width of the conveyor belt; $h$ - the thickness of the conveyor belt; $\mathrm{F}_{\mathrm{W}}$ is the sum of the total resistance to movement of the belt [21, p.12]:

$$
\mathrm{F}_{\mathrm{W}}=\mathrm{F}_{\mathrm{H}}+\mathrm{F}_{\mathrm{N}}+\mathrm{F}_{\mathrm{St}}+\mathrm{F}_{\mathrm{S}} \text {. }
$$

Primary resistances $\mathrm{F}_{\mathrm{H}}$ are associated with the friction of resistance along the conveyor belt, with the exception of special resistances. Primary resistance $\mathrm{F}_{\mathrm{H}}$, assuming a linear relationship between the resistances and the transported load, are determined by the expression [21, p.13]:

$$
d \mathrm{~F}_{\mathrm{H}}=d S \cdot f_{C} \cdot g_{m}\left([\chi]_{0 R}+\left([\chi]_{0}(t, S)+[\chi]_{0 C}\right) \cos \delta_{C}\right),
$$

where $f_{C}$ is coefficient of resistance to movement includes rolling resistance of driving rollers and belt indentation resistance $[21, \mathrm{p} .13] ;(\mathrm{m} / \mathrm{sec} 2) ;[\chi]_{0 R}$ is linear load from rotating parts $[21, \mathrm{p} .8] ; \delta_{C}$ is conveyor section angle $\left[21\right.$, p.9]. The linear load from the rotating parts $[\chi]_{0 R}$ can be calculated as the ratio of the mass of the rotating element (roller) $m_{R}$ to the distance $S_{R}$ between axes of symmetry of the rotating elements [22, p.153]

$$
[\chi]_{0 R}=\frac{m_{R}}{S_{R}} .
$$

The force $\mathrm{F}_{\mathrm{N}}$, taking into account the effect on the movement of secondary resistances, can be expressed in terms of the value of primary resistance to motion $\mathrm{F}_{\mathrm{H}}[21, \mathrm{p} .17]$ :

$$
\mathrm{F}_{\mathrm{N}}=(C-1) \mathrm{F}_{\mathrm{H}} .
$$

For belt conveyor systems with filling factors $\varphi$ in the range from 0.7 to 1.1 , the standard values of the coefficient C are presented in [21, p.17]. For a conveyor section of length $S_{d}>2.0 \mathrm{~km}$ this coefficient is equal $C=1,05$. The force $\mathrm{F}_{\mathrm{St}}$, characterizing the gradient resistance of the conveyor belt and the transported material, is calculated for each section of the part as follows [21, p.17]:

$$
d \mathrm{~F}_{\mathrm{St}}=d S \cdot \sin \delta_{C} \cdot g_{m}\left([\chi]_{0}(t, S)+[\chi]_{0 C}\right) .
$$

The calculation of the force $\mathrm{F}_{\mathrm{S}}$, associated with special resistances in the transport system, is presented in [21, p.18]. The value of $F_{S}$ is determined by the design features of the transport system. For most conveyor-type transport systems, it is assumed

Divide (8) by $d m$, get the value $f(t, S)$ :

$$
\mathrm{F}_{\mathrm{S}}<<\mathrm{F}_{\mathrm{H}}
$$

$$
\frac{d\langle\mu\rangle}{d t}=\frac{1}{\left([\chi]_{0}(t, S)+[\chi]_{0 C}\right)} \frac{\partial R(t, S)}{\partial S}-\frac{1}{\left([\chi]_{0}(t, S)+[\chi]_{0 C}\right)} \frac{\partial F_{W}}{\partial S} .
$$

For the model under consideration, it is believed that stress and strain are related by a linear relationship

$$
\sigma(t, S)=E \varepsilon(t, S), \quad \varepsilon(t, S) \approx 10^{-2},
$$

where $E$ is elastic modulus; $\varepsilon$ is relative deformation of the conveyor belt element. If we introduce the absolute elongation of the conveyor belt $\omega(t, S)$ at a point in time $t$ for the technological position $S$, then the ratio of the elongation $d \omega(t, S)$ of the element of the conveyor belt to the length of the segment $d S$ is the relative deformation of the element

$$
\varepsilon(t, S)=\frac{\partial \omega(t, S)}{\partial S}
$$

If we substitute (9) - (11) in (7) then obtain the equations of oscillation of the conveyor belt

$$
\frac{\partial\langle\mu\rangle}{\partial t}+\langle\mu\rangle \frac{\partial\langle\mu\rangle}{\partial S}=\frac{B h E}{\left([\chi]_{0}(t, S)+[\chi]_{0 C}\right)} \frac{\partial^{2} \omega(t, S)}{\partial S^{2}}-\frac{1}{\left([\chi]_{0}(t, S)+[\chi]_{0 C}\right)} \frac{\partial F_{W}}{\partial S} .
$$




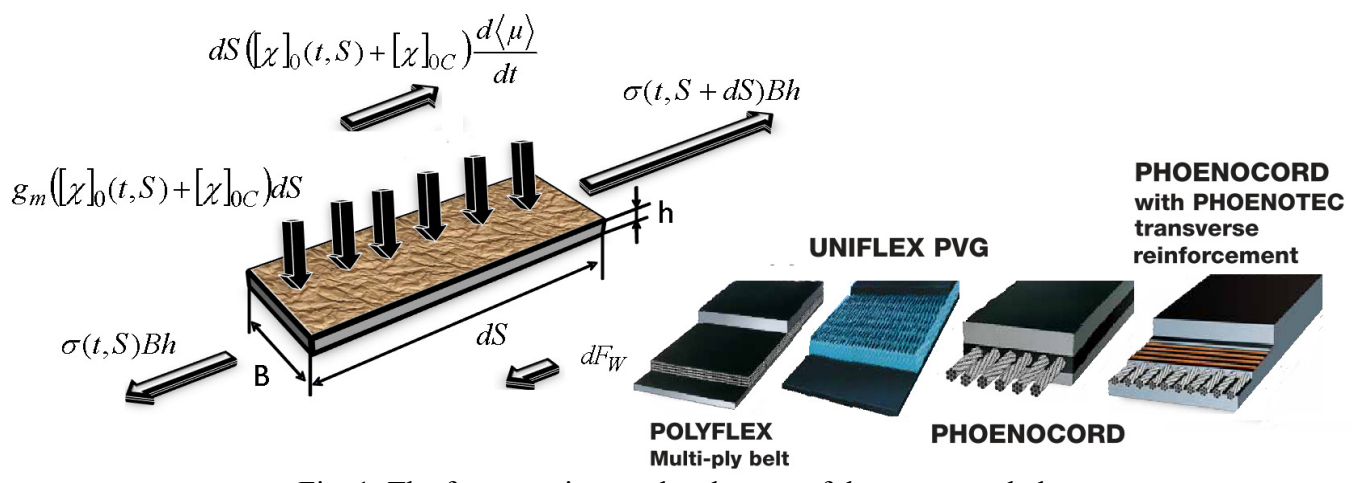

Fig. 1. The forces acting on the element of the conveyor belt

The speed $\langle\mu\rangle$ of the conveyor belt, on which the material is located consists of the speed of the belt in the equilibrium $\mu_{\psi}$ and vibrational $\frac{d \omega(t, S)}{d t}$ parts:

$$
\langle\mu\rangle=\mu_{\psi}+\frac{d \omega(t, S)}{d t}, \quad \frac{d \omega(t, S)}{d t}=\frac{\partial \omega(t, S)}{\partial t}+\langle\mu\rangle \frac{\partial \omega(t, S)}{\partial S} .
$$

Since the relative deformation of the element $\varepsilon(t, S)$ is small (11), then

$$
\frac{d \omega(t, S)}{d t}=\frac{\partial \omega(t, S)}{\partial t}+\langle\mu\rangle \varepsilon(t, S) \approx \frac{\partial \omega(t, S)}{\partial t}, \quad\langle\mu\rangle \varepsilon(t, S)<<\frac{\partial \omega(t, S)}{\partial t} .
$$
obtain

We substitute the expression for the speed of movement of the conveyor belt in the oscillation equation (12),

$$
\begin{aligned}
& \frac{\partial \mu_{\psi}}{\partial t}+\frac{\partial^{2} \omega(t, S)}{\partial t^{2}}+\left(\mu_{\psi}+\frac{\partial \omega(t, S)}{\partial t}\right) \frac{\partial}{\partial S}\left(\mu_{\psi}+\frac{\partial \omega(t, S)}{\partial t}\right)= \\
& =\frac{B h E}{\left([\chi]_{0}(t, S)+[\chi]_{0 C}\right)} \frac{\partial^{2} \omega(t, S)}{\partial S^{2}}-\frac{1}{\left([\chi]_{0}(t, S)+[\chi]_{0 C}\right)} \frac{\partial F_{W}}{\partial S}
\end{aligned}
$$

Belt speed for steady motion is a known quantity that is set by program control of the conveyor line

$$
f_{\psi}(t, S)=\frac{\partial \mu_{\psi}(t, S)}{\partial t}+\mu_{\psi} \frac{\partial \mu_{\psi}(t, S)}{\partial \mathrm{S}} .
$$

One of the main features of conveyor-type transport systems is that within the conveyor section for a steady-state mode of operation, the material at each point of the transport route moves at the same speed, which is equal to the speed of the conveyor belt

$$
f_{\psi}(t)=\frac{\partial \mu_{\psi}}{\partial t}+\mu_{\psi} \frac{\partial \mu_{\psi}}{\partial \mathrm{S}}, \quad \frac{\partial \mu_{\psi}}{\partial \mathrm{S}}=0 .
$$

We introduce the notation

$$
C_{\chi}^{2}(t, S)=\frac{B h E}{\left([\chi]_{0}(t, S)+[\chi]_{0 C}\right)},
$$

and taking into account expression (15), we represent equation (14) with small perturbations

$$
\frac{\partial^{2} \omega(t, S)}{\partial t^{2}}+\left(\mu_{\psi}+\frac{\partial \omega(t, S)}{\partial t}\right) \frac{\partial^{2} \omega(t, S)}{\partial t \partial S}=C_{\chi}^{2}(t, S) \frac{\partial^{2} \omega(t, S)}{\partial S^{2}}-\frac{1}{\left([\chi]_{0}(t, S)+[\chi]_{0 C}\right)} \frac{\partial F_{W}}{\partial S}-f_{\psi}(t) .
$$

The speed of the conveyor belt $\langle\mu\rangle$ can have a large gradient, for example as a result of sudden acceleration or deceleration of the conveyor belt. In this paper, we will pay attention to the steady mode for which condition (10) is satisfied, i.e., there are no large gradients for variable speed. Using the passage to the limit using the limit ratio

$$
\langle\mu\rangle \frac{\partial^{2} \omega(t, S)}{\partial t \partial S}=\langle\mu\rangle \frac{\partial \varepsilon(t, S)}{\partial t} \approx \frac{\langle\mu\rangle \varepsilon(t+\Delta t, S)-\langle\mu\rangle \varepsilon(t, S)}{\Delta t},
$$


and taking into account (13), it follows

$$
\frac{\langle\mu\rangle \varepsilon(t+\Delta t, S)-\langle\mu\rangle \varepsilon(t, S)}{\Delta t}<\frac{1}{\Delta t}\left(\frac{\partial \omega(t+\Delta t, S)}{\partial t}-\frac{\partial \omega(t, S)}{\partial t}\right) \approx \frac{\partial^{2} \omega(t, S)}{\partial t^{2}} .
$$

When you change the length of a segment of the transport route, the density $\left([\chi]_{0}(t, S)+[\chi]_{0 C}\right)$ changes. Let the length of the segment $d S$ changes and becomes equal $(d S+d \omega(t, S)), d S \gg d \omega(t, S)$. In this case, the linear density will change and becomes equal $\left([\chi]_{0}(t, S)+[\chi]_{0 C}\right)+\left(\Delta[\chi]_{0}(t, S)+\Delta[\chi]_{0 C}\right)$. For this segment of the transport route we have

$$
d S\left([\chi]_{0}(t, S)+[\chi]_{0 C}\right)=(d S+d \omega(t, S))\left([\chi]_{0}(t, S)+[\chi]_{0 C}\right)+\left(\Delta[\chi]_{0}(t, S)+\Delta[\chi]_{0 C}\right) .
$$

Neglecting the value of the second-order of smallness $d \omega(t, S)\left(\Delta[\chi]_{0}(t, S)+\Delta[\chi]_{0 C}\right)$, we get

$$
0 \approx d S\left(\Delta[\chi]_{0}(t, S)+\Delta[\chi]_{0 C}\right)+\omega(t, S)\left([\chi]_{0}(t, S)+[\chi]_{0 C}\right) \text {, }
$$

where from

$$
\frac{d \omega(t, S)}{d S} \approx-\frac{\Delta[\chi]_{0}(t, S)+\Delta[\chi]_{0 C}}{[\chi]_{0}(t, S)+[\chi]_{0 C}} \approx \varepsilon
$$

This allows us to represent the square of the function $C_{\chi}{ }^{2}(t, S)$ as an expansion in the vicinity of the unperturbed density $[\chi]_{0 \psi}(t, S)$

$$
\begin{gathered}
C_{\chi}{ }^{2}(t, S) \approx \frac{B h E}{[\chi]_{0 \psi}(t, S)+[\chi]_{0 C}}\left(1-\frac{\Delta[\chi]_{0 \psi}(t, S)+\Delta[\chi]_{0 C}}{[\chi]_{0 \psi}(t, S)+[\chi]_{0 C}}\right)=C_{\psi}{ }^{2}(t, S)(1-\varepsilon), \\
C_{\psi}{ }^{2}(t, S)=\frac{B h E}{[\chi]_{0 \psi}(t, S)+[\chi]_{0 C}} .
\end{gathered}
$$

The function $C_{\psi}{ }^{2}(t, S)$ determines the propagation speed of disturbances along the conveyor belt [36]. Thus, using assumption (10) on the linear dependence of stress and relative deformation, the system of equations for determining the vibrations of the conveyor belt takes the form:

$$
\begin{aligned}
& \frac{\partial[\chi]_{0}(t, S)}{\partial t}+\mu_{\psi}(t) \frac{\partial[\chi]_{0}(t, S)}{\partial S}=\delta(S) \lambda(t), \\
& \frac{\partial^{2} \omega(t, S)}{\partial t^{2}}=C_{\psi}^{2}(t, S) \frac{\partial^{2} \omega(t, S)}{\partial S^{2}}-\frac{1}{\left([\chi]_{0}(t, S)+[\chi]_{0 C}\right)} \frac{\partial F_{W}}{\partial S}-f_{\psi}(t) .
\end{aligned}
$$

We assume that at the initial moment of time the linear density of the material is distributed along the transport route according to the law

$$
[\chi]_{0}(0, S)=\mathrm{H}(S) \Psi(S), \quad \mathrm{H}(S)=\left\{\begin{array}{l}
0, S<0, \\
1, S \geq 0,
\end{array} \quad S \in\left[0 ; S_{d}\right] .\right.
$$

We supplement the system of equations (20) with boundary conditions for an equation that describes oscillatory processes in a transport system. Stresses $\sigma(t, 0)$ and $\sigma\left(t, S_{d}\right)$ are determined by the tension forces of the conveyor belt $T_{1}$ and $T_{4}$ (fig.2).

We write the system of equations for the forces $T_{\mathrm{i}}$, that determine the movement of the belt at the characteristic points of the horizontal conveyor section:

$$
\begin{aligned}
& T_{1}=T_{2} \exp \left(k_{b} \alpha\right) ; \quad T_{3}=T_{2}+F_{\mathrm{W}(2-3)}+F_{\psi(2-3)} ; \quad T_{4}=k_{s} T_{3}, \quad T_{1}=T_{4}+F_{\mathrm{W}(4-1)}+F_{\psi(4-1)}, \\
& F_{\mathrm{H}(2-3)}=S_{d} \cdot f_{C} \cdot g_{m}\left([\chi]_{0 R}+[\chi]_{0 C}\right), \quad F_{\mathrm{H}(4-1)}=F_{\mathrm{H}(2-3)}+f_{C} \cdot g_{m} \int_{0}^{S_{d}}[\chi]_{0}(t, S) d S, \\
& \delta_{C}=0 \text {, } \\
& F_{\mathrm{N}(2-3)}=(C-1) F_{\mathrm{H}(2-3)}, \quad F_{\mathrm{N}(4-1)}=(C-1) F_{\mathrm{H}(4-1)},
\end{aligned}
$$




$$
\begin{array}{ll}
F_{\mathrm{St}(2-3)}=S_{d} \cdot \sin \delta_{C} \cdot g_{m}[\chi]_{0 C}=0, & F_{\mathrm{St}(4-1)}=F_{\mathrm{St}(2-3)}+\sin \delta_{C} \cdot g_{m} \int_{0}^{S_{d}}[\chi]_{0}(t, S) d S=0, \\
F_{\psi(2-3)}=f_{\psi}(t)[\chi]_{0 C} S_{d}, & F_{\psi(4-1)}=f_{\psi}(t)[\chi]_{0 C} S_{d}+f_{\psi}(t) \int_{0}^{S_{d}}[\chi]_{0}(t, S) d S,
\end{array}
$$

where $F_{\psi(2-3)}, F_{\psi(4-1)}$ are forces associated with the acceleration or deceleration of the conveyor belt. We believe that the effects associated with a change in the angular velocity of rotation of the drum are small due to the insignificant magnitude of the moment of inertia of the rollers. Traction moment rotates drum "B". Drum "A" rotates under the action of the frictional force of the belt, resisting movement. Then from the equality

$$
T_{1}=T_{4}+F_{\mathrm{W}(4-1)}+F_{\psi(4-1)}=k_{s} T_{3}+F_{\mathrm{W}(4-1)}+F_{\psi(4-1)}=k_{S}\left(T_{2}+F_{\mathrm{W}(2-3)}+F_{\psi(2-3)}\right)+F_{\mathrm{W}(4-1)}+F_{\psi(4-1)},
$$

is determined the tension of the tape at characteristic points

$$
\begin{gathered}
T_{1}=T_{2} \exp \left(k_{b} \alpha\right)=\left(k_{s} F_{\mathrm{W}(2-3)}+k_{s} F_{\psi(2-3)}+F_{\mathrm{W}(4-1)}+F_{\psi(4-1)}\right) \frac{\exp \left(k_{b} \alpha\right)}{\exp \left(k_{b} \alpha\right)-k_{s}}, \\
T_{2}=\frac{k_{s} F_{\mathrm{W}(2-3)}+k_{s} F_{\psi(2-3)}+F_{\mathrm{W}(4-1)}+F_{\psi(4-1)}}{\exp \left(k_{b} \alpha\right)-k_{s}} \\
T_{3}=T_{2}+F_{\mathrm{W}(2-3)}+F_{\psi}(2-3)=\frac{k_{s} F_{\mathrm{W}(2-3)}+k_{s} F_{\psi}(2-3)+F_{\mathrm{W}(4-1)}+F_{\psi(4-1)}}{\exp \left(k_{b} \alpha\right)-k_{s}}+F_{\mathrm{W}(2-3)}+F_{\psi(2-3)} \\
T_{4}=T_{2} \exp \left(k_{b} \alpha\right)-F_{\mathrm{W}(4-1)}-F_{\psi(4-1)}=\left(k_{s} F_{\mathrm{W}(2-3)}+k_{s} F_{\psi(2-3)}+F_{\mathrm{W}(4-1)}+F_{\psi(4-1)}\right) \frac{\exp \left(k_{b} \alpha\right)}{\exp \left(k_{b} \alpha\right)-k_{s}}-F_{\mathrm{W}(4-1)}-F_{\psi}(4-1)
\end{gathered}
$$

where $k_{b}$ is coefficient of adhesion between the drum and the belt; $k_{s}$ is drum loss coefficient "A"; $\alpha$ is the total girth angle of the drum. For a steel drum in the absence of moisture $k_{b} \approx 0.3, k_{s} \approx 1.03$ [31] and $\alpha=\pi$ we get $\exp \left(k_{b} \alpha\right)=2.56$.

Taking into account the values of the acting forces $T_{1}, T_{4}(21)$, we write down the boundary conditions

$$
\begin{array}{r}
\sigma\left(t, S_{d}\right)=\frac{T_{1}}{B h}=\left.E \frac{\partial \omega(t, S)}{\partial S}\right|_{S=S_{d}}=\frac{1}{B h}\left(k_{S} F_{\mathrm{W}(2-3)}+k_{S} F_{\psi(2-3)}+F_{\mathrm{W}(4-1)}+F_{\psi(4-1)}\right) \frac{\exp \left(k_{b} \alpha\right)}{\exp \left(k_{b} \alpha\right)-k_{s}}, \\
\sigma(t, 0)=\frac{T_{4}}{B h}=\frac{T_{1}-F_{\mathrm{W}(4-1)}-F_{\psi(4-1)}}{B h}=\left.E \frac{\partial \omega(t, S)}{\partial S}\right|_{S=0}=\left.E \frac{\partial \omega(t, S)}{\partial S}\right|_{S=S_{d}}-\frac{F_{\mathrm{W}(4-1)}+F_{\psi(4-1)}}{B h} .
\end{array}
$$

We supplement the system of equations with initial conditions. Consider the steady mode of operation of the conveyor line, when at the initial time there are no oscillations

$$
\left.\frac{\partial \omega(t, S)}{\partial t}\right|_{t=0}=0 .
$$

The stress of the conveyor belt at the initial time is determined by the initial distribution of the material along the technological route $\Psi(S)$ and the acceleration of the conveyor belt $f_{\psi}(t)$. Then

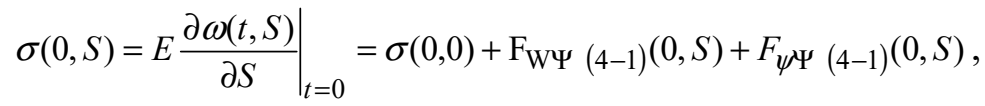

$$
\begin{aligned}
& \sigma(0,0)=\left.\frac{T_{4}}{B h}\right|_{t=0}=\left.E \frac{\partial \omega(0, S)}{\partial S}\right|_{S=0}, \\
& F_{\mathrm{H} \Psi(4-1)}(0, S)=f_{C} \cdot g_{m} \int_{0}^{S}\left([\chi]_{0 R}+[\chi]_{0 C}+\Psi(\zeta)\right) d \zeta, \quad F_{\mathrm{N} \Psi(4-1)}(0, S)=(C-1) F_{\mathrm{H} \Psi(4-1)}(t, S), \\
& F_{\psi \Psi(4-1)}(0, S)=f_{\psi}(0) \int_{0}^{S}\left([\chi]_{0 R}+[\chi]_{0 C}+\Psi(\zeta)\right) d \zeta, \quad[\chi]_{0}(0, S)=\Psi(S)
\end{aligned}
$$




$$
\mathrm{F}_{\mathrm{W} \Psi(4-1)}(0, S)=F_{\mathrm{H} \Psi(4-1)}(0, S)+F_{\mathrm{N} \Psi(4-1)}(0, S) .
$$

Combining the system of equations (20), (21) with the boundary (24) and initial (25), (26) conditions, we obtain a two-moment model of the transport system that allows us to study dynamic stresses in the conveyor belt depending on changes in flow parameters $[\chi]_{0}(t, S),[\chi]_{1}(t, S)$. Equations (7) and (9) can be used to study the scattering of the material during its transportation.

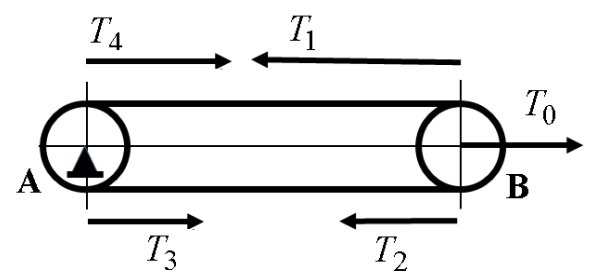

Fig. 2. The scheme of the tension of the conveyor belt

Using the notation

$$
\begin{array}{ccc}
\tau=\frac{t}{T_{d}}, \quad \xi=\frac{S}{S_{d}}, \quad \theta_{0}(\tau, \xi)=\frac{[\chi]_{0}(t, S)}{[\chi]_{0 \max }}, \quad \psi(\xi)=\frac{\Psi(S)}{[\chi]_{0 \max }}, \quad \gamma(\tau)=\lambda(t) \frac{T_{d}}{S_{d}[\chi]_{0 \max }}, \\
g(\tau)=\mu_{\psi}(t) \frac{T_{d}}{S_{d}}, & \delta(\xi)=S_{d} \delta(S),
\end{array}
$$

equation (20) with boundary conditions (22) takes a dimensionless form:

$$
\frac{\partial \theta_{0}(\tau, \xi)}{\partial \tau}+g(\tau) \frac{\partial \theta_{0}(\tau, \xi)}{\partial \xi}=\delta(\xi) \gamma(\tau), \quad \theta_{0}(0, \xi)=\mathrm{H}(\xi) \psi(\xi), \quad 0 \leq \gamma(\tau) \leq \gamma_{\max }
$$

The solution of equation (28) allows you to determine the state of the linear density of the material $\theta_{0}(\tau, \xi)$ along the transport route at an arbitrary point in time at an arbitrary point $\xi$

$$
\theta_{0}(\tau, \xi)=(H(\xi)-H(\xi-G(\tau))) \frac{\gamma\left(G^{-1}(G(\tau)-\xi)\right)}{g\left(G^{-1}(G(\tau)-\xi)\right)}+\mathrm{H}(\xi-G(\tau)) \psi(\xi-G(\tau)), \quad G(\tau)=\int_{0}^{\tau} g(\alpha) d \alpha, \quad \tau=G^{-1}(\xi) .
$$

The linear density of the material along the transport route $\theta_{0}(\tau, \xi)$ at an arbitrary point in time $\tau$ can be determined, if the intensity $\gamma(\tau)$ of the rock input to the entrance of the conveyor line and the speed of the conveyor belt $g(\tau)$ are known. The material flow along the conveyor line $\theta_{1}(\tau, \xi)$ can be obtained as a result of the product of the linear density of the material $\theta_{0}(\tau, \xi)$ and the speed of movement of the material $g(\tau)$

$$
\theta_{1}(\tau, \xi)=(H(\xi)-H(\xi-G(\tau))) \frac{\gamma\left(G^{-1}(G(\tau)-\xi)\right)}{g\left(G^{-1}(G(\tau)-\xi)\right)} g(\tau)+\mathrm{H}(\xi-G(\tau)) \psi(\xi-G(\tau)) g(\tau) .
$$

An analysis of the solution (29), (30) is given in [33]. Using the notation

$$
\begin{gathered}
\omega_{0}(\tau, \xi)=\frac{\omega(t, S)}{\omega_{\max }}, \quad \omega_{\max }=\frac{\sigma_{b} S_{d}}{E}, \quad \theta_{\mathrm{C}}=\frac{[\chi]_{0 \mathrm{C}}}{[\chi]_{0 \max }}, \quad \theta_{\mathrm{R}}=\frac{[\chi]_{0 \mathrm{R}}}{[\chi]_{0 \max }}, \\
v_{b}=\frac{C f_{C} g_{m}\left([\chi]_{0 \max }+[\chi]_{0 C}\right) S_{d}}{\sigma_{b} B h}, \quad v_{f}=\frac{\left([\chi]_{0 \max }+[\chi]_{0 C}\right) f_{\psi}(t) S_{d}}{\sigma_{b} B h}, v_{g}^{2}=\frac{B h E}{\left([\chi]_{0 \max }+[\chi]_{0 C}\right)}\left(\frac{T_{d}}{S_{d}}\right)^{2},
\end{gathered}
$$

equation (21), which describes oscillatory processes in a transport system, takes a dimensionless form

$$
\frac{\partial^{2} \omega_{0}(\tau, \xi)}{\partial \tau^{2}}=v_{g}{ }^{2} \frac{\partial^{2} \omega_{0}(\tau, \xi)}{\partial \xi^{2}} \frac{1+\theta_{\mathrm{C}}}{\theta_{0}(\tau, \xi)+\theta_{\mathrm{C}}}-v_{g}{ }^{2}\left(v_{b}+v_{f}\right)-v_{g}{ }^{2} v_{b} \frac{\theta_{\mathrm{R}}}{\theta_{0}(\tau, \xi)+\theta_{\mathrm{C}}}
$$

with boundary conditions (24) 


$$
\begin{gathered}
\frac{\sigma\left(t, S_{d}\right)}{\sigma_{b}}=\left.\frac{\partial \omega_{0}(t, \xi)}{\partial \xi}\right|_{\xi=1}=\left(\left(k_{s}+1\right)\left(v_{b}+v_{f}\right) \frac{\theta_{\mathrm{C}}}{1+\theta_{\mathrm{C}}}+\left(k_{s}+1\right) v_{b} \frac{\theta_{\mathrm{R}}}{1+\theta_{\mathrm{C}}}+\left(v_{b}+v_{f}\right) \int_{0}^{1} \frac{\theta_{0}(\tau, \xi)}{1+\theta_{\mathrm{C}}} d \xi\right)\left(\frac{\exp \left(k_{b} \alpha\right)}{\exp \left(k_{b} \alpha\right)-k_{s}}\right), \\
\frac{\sigma(t, 0)}{\sigma_{b}}=\left.\frac{\partial \omega_{0}(t, \xi)}{\partial \xi}\right|_{\xi=0}=\left.\frac{\partial \omega_{0}(t, \xi)}{\partial \xi}\right|_{\xi=1}-\frac{F_{\mathrm{W}(4-1)}+F_{\psi}(4-1)}{\sigma_{b} B h}=\left.\frac{\partial \omega_{0}(t, \xi)}{\partial \xi}\right|_{\xi=1}-v_{b} \frac{\theta_{\mathrm{R}}}{1+\theta_{\mathrm{C}}}-\left(v_{b}+v_{f}\right) \int_{0}^{1} \frac{\theta_{\mathrm{C}}+\theta_{0}(\tau, \xi)}{1+\theta_{\mathrm{C}}} d \xi,
\end{gathered}
$$

and initial conditions (25), (26)

$$
\begin{gathered}
\left.\frac{\partial \omega_{0}(\tau, \xi)}{\partial \tau}\right|_{\tau=0}=0, \\
\frac{\sigma(0, S)}{\sigma_{b}}=\frac{\partial \omega_{0}(0, S)}{\partial \xi}=\left.\frac{\partial \omega_{0}(0, \xi)}{\partial \xi}\right|_{\xi=1}-v_{b} \int_{\xi}^{1} \frac{\theta_{\mathrm{C}}+\theta_{\mathrm{R}}+\psi(\xi)}{1+\theta_{\mathrm{C}}} d \xi-v_{f} \int_{\xi}^{1} \frac{\theta_{\mathrm{C}}+\psi(\xi)}{1+\theta_{\mathrm{C}}} d \xi, \theta_{0}(0, \xi)=\psi(\xi),
\end{gathered}
$$

where

$$
\frac{\sigma\left(0, S_{d}\right)}{\sigma_{b}}=\left.\frac{\partial \omega_{0}(0, \xi)}{\partial \xi}\right|_{\xi=1}=\left(\left(k_{s}+1\right)\left(v_{b}+v_{f}\right) \frac{\theta_{\mathrm{C}}}{1+\theta_{\mathrm{C}}}+\left(k_{s}+1\right) v_{b} \frac{\theta_{\mathrm{R}}}{1+\theta_{\mathrm{C}}}+\left(v_{b}+v_{f}\right) \int_{0}^{1} \frac{\psi(\xi)}{1+\theta_{\mathrm{C}}} d \xi\right)\left(\frac{\exp \left(k_{b} \alpha\right)}{\exp \left(k_{b} \alpha\right)-k_{s}}\right) .
$$

\section{SOLUTION ANALYSIS FOR SMALL LOADED CONVEYOR LINES}

Consider the solution of the system of equations (30)-(35) for the case of the initial movement of the conveyor, when the conveyor line is underloaded. The specific weight of the material along such conveyor lines is small compared to the specific weight of the conveyor belt

$$
\theta_{0}(\tau, \xi)<\theta_{\mathrm{C}}, \quad \psi(\xi)=\theta_{0}(0, \xi)<<\theta_{\mathrm{C}} .
$$

Based on the above assumption, the system of equations (30) - (35) takes the form

$$
\begin{gathered}
\theta_{1}(\tau, \xi)=(H(\xi)-H(\xi-G(\tau))) \frac{\gamma\left(G^{-1}(G(\tau)-\xi)\right)}{g\left(G^{-1}(G(\tau)-\xi)\right)} g(\tau)+\mathrm{H}(\xi-G(\tau)) \psi(\xi-G(\tau)) g(\tau) . \\
\frac{\partial^{2} \omega_{0}(\tau, \xi)}{\partial \tau^{2}}=v_{g}^{2} \frac{\partial^{2} \omega_{0}(\tau, \xi)}{\partial \xi^{2}} \frac{1+\theta_{\mathrm{C}}}{\theta_{\mathrm{C}}}-v_{g}^{2} v_{f}-v_{g}{ }^{2} v_{b}\left(1+\frac{\theta_{\mathrm{R}}}{\theta_{\mathrm{C}}}\right)
\end{gathered}
$$

with boundary conditions (32), (33)

$$
\begin{aligned}
\left.\frac{\partial \omega_{0}(t, \xi)}{\partial \xi}\right|_{\xi=1}= & \left(\left(k_{s}+1\right) v_{b} \frac{\theta_{\mathrm{C}}}{1+\theta_{\mathrm{C}}}\left(1+\frac{\theta_{\mathrm{R}}}{\theta_{\mathrm{C}}}\right)+\left(k_{s}+1\right) v_{f} \frac{\theta_{\mathrm{C}}}{1+\theta_{\mathrm{C}}}\right)\left(\frac{\exp \left(k_{b} \alpha\right)}{\exp \left(k_{b} \alpha\right)-k_{s}}\right), \\
& \left.\frac{\partial \omega_{0}(t, \xi)}{\partial \xi}\right|_{\xi=0}=\left.\frac{\partial \omega_{0}(t, \xi)}{\partial \xi}\right|_{\xi=1}-v_{f} \frac{\theta_{\mathrm{C}}}{1+\theta_{\mathrm{C}}}-v_{b} \frac{\theta_{\mathrm{C}}}{1+\theta_{\mathrm{C}}}\left(1+\frac{\theta_{\mathrm{R}}}{\theta_{\mathrm{C}}}\right),
\end{aligned}
$$

and initial conditions (34), (35)

$$
\left.\frac{\partial \omega_{0}(\tau, \xi)}{\partial \tau}\right|_{\tau=0}=0, \quad \frac{\partial \omega_{0}(0, \xi)}{\partial \xi}=\left.\frac{\partial \omega_{0}(0, \xi)}{\partial \xi}\right|_{\xi=1}-v_{b} \frac{\theta_{\mathrm{C}}}{1+\theta_{\mathrm{C}}}\left(1+\frac{\theta_{\mathrm{R}}}{\theta_{\mathrm{C}}}\right)(1-\xi)-v_{f} \frac{\theta_{\mathrm{C}}}{1+\theta_{\mathrm{C}}}(1-\xi) .
$$

During the initial movement of the conveyor belt, three characteristic phases should be distinguished: a) the period of time of the initial start-up, when the conveyor belt goes from rest to moving along the entire route; $b$ ) the phase of formation of the static force along the conveyor belt; c) the phase of acceleration of the conveyor belt to the rated speed. Let us dwell on the analysis of the last phase of the start of the conveyor belt. The acceleration phase of the conveyor belt to the rated speed is characterized by a constant value of the traction moment [37, p. 95] and a constant value of the acceleration of the elements of the conveyor belt. This allows us to simplify equation (36) 


$$
\begin{gathered}
\frac{\partial^{2} \omega_{0}(\tau, \xi)}{\partial \tau^{2}}=v_{1}{ }^{2} \frac{\partial^{2} \omega_{0}(\tau, \xi)}{\partial \xi^{2}}-v_{2}^{2}, \\
v_{1}^{2}=v_{g}{ }^{2} \frac{1+\theta_{\mathrm{C}}}{\theta_{\mathrm{C}}}, \quad v_{2}{ }^{2}=v_{g}{ }^{2} v_{f}+v_{g}{ }^{2} v_{b}\left(1+\frac{\theta_{\mathrm{R}}}{\theta_{\mathrm{C}}}\right)
\end{gathered}
$$

with boundary conditions

$$
\begin{gathered}
\left.\frac{\partial \omega_{0}(\tau, \xi)}{\partial \xi}\right|_{\xi=1}=\alpha_{1},\left.\quad \frac{\partial \omega_{0}(t, \xi)}{\partial \xi}\right|_{\xi=0}=\alpha_{1}-\alpha_{12}, \\
\alpha_{1}=\left(\left(k_{s}+1\right) v_{b} \frac{\theta_{\mathrm{C}}}{1+\theta_{\mathrm{C}}}\left(1+\frac{\theta_{\mathrm{R}}}{\theta_{\mathrm{C}}}\right)+\left(k_{s}+1\right) v_{f} \frac{\theta_{\mathrm{C}}}{1+\theta_{\mathrm{C}}}\right)\left(\frac{\exp \left(k_{b} \alpha\right)}{\exp \left(k_{b} \alpha\right)-k_{s}}\right), \\
\alpha_{12}=v_{b} \frac{\theta_{\mathrm{C}}}{1+\theta_{\mathrm{C}}}\left(1+\frac{\theta_{\mathrm{R}}}{\theta_{\mathrm{C}}}\right)+v_{f} \frac{\theta_{\mathrm{C}}}{1+\theta_{\mathrm{C}}}=\left(v_{b} \frac{\theta_{\mathrm{C}}}{1+\theta_{\mathrm{C}}}\left(1+\frac{\theta_{\mathrm{R}}}{\theta_{\mathrm{C}}}\right)+v_{f} \frac{\theta_{\mathrm{C}}}{1+\theta_{\mathrm{C}}}\right) \frac{v_{g}^{2} \frac{1+\theta_{\mathrm{C}}}{v_{g}} \frac{\theta_{\mathrm{C}}}{\frac{1+\theta_{\mathrm{C}}}{\theta_{\mathrm{C}}}}=\frac{v_{2}^{2}}{v_{g}^{2} \frac{1+\theta_{\mathrm{C}}}{\theta_{\mathrm{C}}}}=\frac{v_{2}^{2}}{v_{1}^{2}},}{}
\end{gathered}
$$

and initial conditions

$$
\left.\frac{\partial \omega_{0}(\tau, \xi)}{\partial \tau}\right|_{\tau=0}=0, \quad \frac{\partial \omega_{0}(0, \xi)}{\partial \xi}=\alpha_{1}-\alpha_{12}(1-\xi),
$$

where $v_{1}{ }^{2}, v_{2}{ }^{2}, \alpha_{1}, \alpha_{12}$ are constant coefficient, $\alpha_{1 M}(\tau)$ is the stresses, due to vibration of the traction drum as a result of providing the required traction moment.

The solution to equation (9) is sought in the form

$$
\omega_{0}(\tau, \xi)=\omega_{00}(\tau, \xi)+\omega_{01}(\tau, \xi) .
$$

Choose a function $\omega_{01}(\tau, \xi)$ in the form

$$
\omega_{01}(\tau, \xi)=A(\tau) \xi^{2}+B(\tau) \xi+C_{01} .
$$

where $C_{01}$ is an unknown constant. We define the coefficients $A(\tau), B(\tau)$ in such a way as to ensure the presence of boundary conditions for the function $\omega_{00}(\tau, \xi)$ in the form

$$
\left.\frac{\partial \omega_{00}(\tau, \xi)}{\partial \xi}\right|_{\xi=1}=0,\left.\quad \frac{\partial \omega_{00}(t, \xi)}{\partial \xi}\right|_{\xi=0}=0, \quad \frac{\partial \omega_{00}(t, \xi)}{\partial \xi}=\frac{\partial \omega_{0}(t, \xi)}{\partial \xi}-\frac{\partial \omega_{01}(t, \xi)}{\partial \xi} .
$$

Then the coefficients $A(\tau), B(\tau)$ we obtain as a result of solving the system of equations

$$
\begin{aligned}
& \left.\frac{\partial \omega_{00}(\tau, \xi)}{\partial \xi}\right|_{\xi=1}=\left.\frac{\partial \omega_{0}(\tau, \xi)}{\partial \xi}\right|_{\xi=1}-\left.\frac{\partial \omega_{01}(\tau, \xi)}{\partial \xi}\right|_{\xi=1}=\alpha_{1}-2 A(\tau)-B(\tau)=0, \\
& \left.\frac{\partial \omega_{00}(\tau, \xi)}{\partial \xi}\right|_{\xi=0}=\left.\frac{\partial \omega_{0}(\tau, \xi)}{\partial \xi}\right|_{\xi=0}-\left.\frac{\partial \omega_{01}(\tau, \xi)}{\partial \xi}\right|_{\xi=0}=\alpha_{1}-\alpha_{21}-B(\tau)=0 .
\end{aligned}
$$

From the solution of the system of equations follows

$$
\begin{aligned}
& A(\tau)=\frac{\alpha_{12}}{2}=\frac{1}{2} \frac{v_{2}^{2}}{v_{1}^{2}}, \quad B(\tau)=\alpha_{1}-\alpha_{21}=\alpha_{1}-\frac{v_{2}^{2}}{v_{1}^{2}}, \\
& \omega_{01}(\tau, \xi)=\frac{1}{2} \frac{v_{2}^{2}}{v_{1}^{2}} \xi^{2}+\left(\alpha_{1}-\frac{v_{2}^{2}}{v_{1}^{2}}\right) \xi+C_{01} .
\end{aligned}
$$

Substituting solution (42) into equation (39) and into the initial conditions (40), (41), we obtain the initialboundary value problem for the function $\omega_{00}(\tau, \xi)$

$$
\frac{\partial^{2} \omega_{00}(\tau, \xi)}{\partial \tau^{2}}=v_{1}^{2} \frac{\partial^{2} \omega_{00}(\tau, \xi)}{\partial \xi^{2}}-\frac{\partial^{2} \alpha_{12}}{\partial \tau^{2}}\left(\frac{\xi^{2}}{2}-\xi\right)
$$




$$
\begin{gathered}
\left.\frac{\partial \omega_{00}(\tau, \xi)}{\partial \xi}\right|_{\xi=1}=0,\left.\frac{\partial \omega_{00}(\tau, \xi)}{\partial \xi}\right|_{\xi=0}=0,\left.\quad \frac{\partial \omega_{00}(\tau, \xi)}{\partial \xi}\right|_{\tau=0}=\left.\frac{\partial \omega_{0}(\tau, \xi)}{\partial \xi}\right|_{\tau=0}-\left.\frac{\partial \omega_{01}(\tau, \xi)}{\partial \xi}\right|_{\tau=0}=0 \\
\left.\frac{\partial \omega_{00}(\tau, \xi)}{\partial \tau}\right|_{\tau=0}=\left.\frac{\partial \omega_{0}(\tau, \xi)}{\partial \tau}\right|_{\tau=0}-\left.\frac{\partial \omega_{01}(\tau, \xi)}{\partial \tau}\right|_{\tau=0}=-\left.\frac{\partial \alpha_{12}}{\partial \tau}\left(\frac{\xi^{2}}{2}-\xi\right)\right|_{\tau=0} .
\end{gathered}
$$

We consider two cases where the acceleration of the conveyor belt is constant $v_{f}=v_{f 0}=$ const and the case where the acceleration of the conveyor belt varies linearly with time $v_{f}=v_{f 0}+v_{f 1} \tau$.

In the case where the acceleration of the conveyor belt is constant $v_{f}=v_{f 0}$, the derivative of the function $\alpha_{12}$ is zero

and the boundary value problem (43) takes the form

$$
\frac{\partial \alpha_{12}}{\partial \tau}=0
$$

$$
\begin{aligned}
& \frac{\partial^{2} \omega_{00}(\tau, \xi)}{\partial \tau^{2}}=v_{1}^{2} \frac{\partial^{2} \omega_{00}(\tau, \xi)}{\partial \xi^{2}}, \\
& \left.\quad \frac{\partial \omega_{00}(\tau, \xi)}{\partial \xi}\right|_{\xi=1}=0,\left.\quad \frac{\partial \omega_{00}(\tau, \xi)}{\partial \xi}\right|_{\xi=0}=0,\left.\quad \frac{\partial \omega_{00}(\tau, \xi)}{\partial \tau}\right|_{\tau=0}=0,\left.\quad \frac{\partial \omega_{00}(\tau, \xi)}{\partial \xi}\right|_{\tau=0}=0 .
\end{aligned}
$$

The solution of problem (44) is presented in the form

$$
\omega_{00}(\tau, \xi)=\sum_{n=0}^{\infty} T_{n}(\tau) X_{n}(\xi),
$$

where the function $X_{n}(\xi)$ is determined from the solution of the Sturm-Liouville problem. Using the boundary conditions, we write the solutions to the problem in the following form

$$
\omega_{00}(\tau, \xi)=\sum_{n=0}^{\infty} T_{n}(\tau) \cos (\pi n \xi)
$$

At the initial time, the rate of change of the function $\omega_{00}(\tau, \xi)$ is zero. From this condition follows

$$
\left.\frac{\partial \omega_{00}(\tau, \xi)}{\partial \tau}\right|_{\tau=0}=0 \quad \Rightarrow \quad \omega_{00}(\tau, \xi)=\sum_{n=0}^{\infty} G_{n} \cos \left(\pi n v_{1} \tau\right) \cos (\pi n \xi) .
$$

The values of the coefficients $G_{n}$ are determined from the second initial condition

$$
\left.\frac{\partial \omega_{00}(\tau, \xi)}{\partial \xi}\right|_{\tau=0}=-\sum_{n=0}^{\infty} \pi n G_{n} \sin (\pi n \xi)=0 .
$$

Equality holds if $G_{n}=0$. Э This is consistent with the decision

$$
\omega_{00}(\tau, \xi)=0 .
$$

Thus, in the presence of acceleration of the conveyor belt of constant magnitude, there are no oscillations in the belt. Elongation of the tape along the conveyor can be represented by the expression.

$$
\omega_{0}(\tau, \xi)=\omega_{00}(\tau, \xi)+\omega_{01}(\tau, \xi)=\frac{1}{2} \frac{v_{2}^{2}}{v_{1}^{2}} \xi^{2}+\left(\alpha_{1}-\frac{1}{2} \frac{v_{2}^{2}}{v_{1}^{2}}\right) \xi+C_{01} .
$$

The constant $C_{01}$ is determined from the condition of the minimum allowable stress $\omega_{\min }$, ensuring the adhesion of the tape with the drum to create traction in the transport system with a given limit on the allowable amount of sagging of the tape. This allows us to write down the inequality

$$
\omega_{01}(\xi)=\frac{1}{2} \frac{v_{2}^{2}}{v_{1}^{2}} \xi^{2}+\left(\alpha_{1}-\frac{v_{2}^{2}}{v_{1}^{2}}\right) \xi+C_{01} \geq \omega_{\min 0} .
$$


Taking into account the last condition, we write the solution of the equation in the form

$$
\omega_{01}(0)=\frac{1}{2} \frac{v_{2}^{2}}{v_{1}^{2}} \xi^{2}+\left(\alpha_{1}-\frac{v_{2}^{2}}{v_{1}^{2}}\right) \xi+\omega_{\min 0} .
$$

We turn to the second case when the acceleration of the conveyor belt varies with time according to the linear law $v_{f}=v_{f 0}+v_{f 1} \tau$. Then

$$
\frac{\partial \alpha_{12}}{\partial \tau}=\frac{v_{g}^{2} v_{f 1}}{v_{1}^{2}}, \quad v_{2}^{2}=v_{g}^{2}\left(v_{f 0}+v_{f 1} \tau\right)+v_{g}^{2} v_{b}\left(1+\frac{\theta_{\mathrm{R}}}{\theta_{\mathrm{C}}}\right)
$$

and the boundary value problem (43) takes the form

$$
\begin{aligned}
& \frac{\partial^{2} \omega_{00}(\tau, \xi)}{\partial \tau^{2}}=v_{1}^{2} \frac{\partial^{2} \omega_{00}(\tau, \xi)}{\partial \xi^{2}} \\
& \left.\frac{\partial \omega_{00}(\tau, \xi)}{\partial \xi}\right|_{\xi=1}=0,\left.\quad \frac{\partial \omega_{00}(\tau, \xi)}{\partial \xi}\right|_{\xi=0}=0,\left.\quad \frac{\partial \omega_{00}(\tau, \xi)}{\partial \xi}\right|_{\tau=0}=0 \\
& \left.\frac{\partial \omega_{00}(\tau, \xi)}{\partial \tau}\right|_{\tau=0}=-\frac{v_{g}{ }^{2} v_{f 1}}{v_{1}^{2}}\left(\frac{\xi^{2}}{2}-\xi\right)=\mathrm{Z}(\xi) .
\end{aligned}
$$

Using the results of the previous problem for the case $v_{f}=v_{f 0}=$ const, considering two zero boundaries and one zero initial condition (47), we look for the solution to the initial boundary-value problem (46) in the form

$$
\omega_{00}(\tau, \xi)=\sum_{n=0}^{\infty} G_{n} \sin \left(\pi n v_{1} \tau\right) \cos (\pi n \xi)
$$

We determine the unknown coefficients $G_{n}$ from the initial condition (48)

$$
\left.\frac{\partial \omega_{00}(\tau, \xi)}{\partial \tau}\right|_{\tau=0}=\pi v_{1} \sum_{n=0}^{\infty} n G_{n} \cos (\pi n \xi)=-\frac{v_{g}{ }^{2} v_{f 1}}{v_{1}^{2}}\left(\frac{\xi^{2}}{2}-\xi\right)
$$

Emerging dynamic stresses in the conveyor belt can be represented as $\frac{\partial \omega_{00}(\tau, \xi)}{\partial \xi}=-\pi \sum_{n=0}^{\infty} n G_{n} \sin \left(\pi n v_{1} \tau\right) \sin (\pi n \xi)=-\pi \sum_{n=0}^{\infty} n G_{n}\left(\frac{\cos \left(\pi n\left[\xi-v_{1} \tau\right]\right)-\cos \left(\pi n\left[\xi+v_{1} \tau\right]\right)}{2}\right)=\frac{\Omega\left(\xi-v_{1} \tau\right)-\Omega\left(\xi+v_{1} \tau\right)}{2}$

We transform the solution (49) to the form

$$
\omega_{00}(\tau, \xi)=W_{1}\left(\xi+v_{1} \tau\right)+W_{2}\left(\xi-v_{1} \tau\right)
$$

We define $W_{1}\left(\xi+v_{1} \tau\right), W_{2}\left(\xi-v_{1} \tau\right)$ from conditions (47), (48):

$$
\left.\frac{\partial \omega_{00}(\tau, \xi)}{\partial \xi}\right|_{\tau=0}=\frac{d W_{1}(\xi)}{d \xi}+\frac{d W_{2}(\xi)}{d \xi}=0,\left.\quad \frac{\partial \omega_{00}(\tau, \xi)}{\partial \tau}\right|_{\tau=0}=v_{1} \frac{d W_{1}(\xi)}{d \xi}-v_{1} \frac{d W_{2}(\xi)}{d \xi}=-\frac{v_{g}^{2} v_{f 1}}{v_{1}^{2}}\left(\frac{\xi^{2}}{2}-\xi\right)=\mathrm{Z}(\xi)
$$

Integrating the equalities, we obtain

$$
W_{1}(\xi)+W_{2}(\xi)=C_{w 1}, \quad W_{1}(\xi)-W_{2}(\xi)=\frac{1}{v_{1}} \int_{\xi_{0}}^{\xi} \mathrm{Z}(\alpha) d \alpha+C_{w 2} .
$$

where $\xi_{0}, C_{w 1}, C_{w 2}$ is constant coefficients. The constant $C_{w 1}$ is equal to zero due to the choice of the form of functions $W_{1}(\xi), W_{2}(\xi)(50)$. We solve the system of equations, we find

$$
W_{1}(\xi)=\frac{1}{2 v_{1}} \int_{\xi_{0}}^{\xi} \mathrm{Z}(\alpha) d \alpha+\frac{C_{w 2}}{2}, \quad W_{2}(\xi)=-\frac{1}{2 v_{1}} \int_{\xi_{0}}^{\xi} \mathrm{Z}(\alpha) d \alpha-\frac{C_{w 2}}{2}
$$

Substituting (51) into (50), we obtain

$$
\omega_{00}(\tau, \xi)=\frac{1}{2 v_{1}} \int_{\xi-v_{1} \tau}^{\xi+v_{1} \tau} \mathrm{Z}(\alpha) d \alpha
$$


The expression for the emerging dynamic stresses of the conveyor belt has the form

$$
\frac{\partial \omega_{00}(\tau, \xi)}{\partial \xi}=\frac{Z\left(\xi+v_{1} \tau\right)-Z\left(\xi-v_{1} \tau\right)}{2 v_{1}}
$$

The properties of the function $\mathrm{Z}(\alpha)$ follow from the boundary conditions (47)

$$
\begin{array}{ll}
\left.\frac{\partial \omega_{00}(\tau, \xi)}{\partial \xi}\right|_{\xi=0}=\frac{Z\left(v_{1} \tau\right)-Z\left(-v_{1} \tau\right)}{2 v_{1}}=0, & Z(\beta)=Z(-\beta), \\
\left.\frac{\partial \omega_{00}(\tau, \xi)}{\partial \xi}\right|_{\xi=1}=\frac{Z\left(1+v_{1} \tau\right)-Z\left(1-v_{1} \tau\right)}{2 v_{1}}=0, & Z\left(\beta_{11}\right)=Z\left(2-\beta_{11}\right), \quad \beta_{11}=\left(1+v_{1} \tau\right) .
\end{array}
$$

Since the function $\mathrm{Z}(\beta)$ (54) is even and the value $\tau$ is arbitrary, it follows

$$
\mathrm{Z}(2-\beta)=\mathrm{Z}(\beta)=\mathrm{Z}(-\beta), \quad \mathrm{Z}(2+\beta)=\mathrm{Z}(\beta) .
$$

The function $\mathrm{Z}(\beta)$ is an even function of period 2. The general solution of the problem takes the form

$$
\begin{aligned}
& \omega_{0}(\tau, \xi)=\frac{1}{2} \frac{v_{2}^{2}}{v_{1}^{2}} \xi^{2}+\left(\alpha_{1}-\frac{v_{2}^{2}}{v_{1}^{2}}\right) \xi+\omega_{\min 0}+\frac{1}{2 v_{1}} \int_{\xi-v_{1} \tau}^{\xi+v_{1} \tau} \mathrm{Z}(\alpha) d \alpha, \\
& \frac{\partial \omega_{0}(\tau, \xi)}{\partial \xi}=\frac{v_{2}^{2}}{v_{1}^{2}} \xi+\left(\alpha_{1}-\frac{v_{2}^{2}}{v_{1}^{2}}\right)+\frac{\mathrm{Z}\left(\xi+v_{1} \tau\right)-\mathrm{Z}\left(\xi-v_{1} \tau\right)}{2 v_{1}} .
\end{aligned}
$$

We define the point of the transport route at which the maximum dynamic stresses of the conveyor belt occur. We introduce the variable $\tau_{n}$ so that

$$
0 \leq v_{1} \tau_{n}-2 n<2, \quad \tau_{n}=\tau-\frac{2 n}{v_{1}} .
$$

Then, due to the periodicity of function (55), it follows

$$
\begin{array}{ll}
\mathrm{Z}\left(\xi+v_{1} \tau\right)=\mathrm{Z}\left(\xi+v_{1} \tau-2 n\right)=\mathrm{Z}\left(\xi+v_{1}\left(\tau-\frac{2 n}{v_{1}}\right)\right)=\mathrm{Z}\left(\xi+v_{1} \tau_{n}\right)=\mathrm{Z}\left(\beta_{1}\right), & \beta_{1}=\xi+v_{1} \tau_{n}, \\
\mathrm{Z}\left(\xi-v_{1} \tau\right)=\mathrm{Z}\left(\xi-v_{1} \tau+2 n\right)=\mathrm{Z}\left(\xi-v_{1}\left(\tau-\frac{2 n}{v_{1}}\right)\right)=\mathrm{Z}\left(\xi-v_{1} \tau_{n}\right)=\mathrm{Z}\left(\beta_{2}\right), & \beta_{2}=\xi-v_{1} \tau_{n} .
\end{array}
$$

We calculate the value of dynamic stresses (53) arising in the conveyor belt

$$
\frac{\partial \omega_{00}(\tau, \xi)}{\partial \xi}=\frac{Z\left(\xi+v_{1} \tau\right)-\mathrm{Z}\left(\xi-v_{1} \tau\right)}{2 v_{1}}=\mathrm{Z}_{0}\left(\beta_{1}, \beta_{2}\right), \quad \mathrm{Z}(\beta)=v_{d}\left(\frac{\beta^{2}}{2}-\beta\right), \quad v_{d}=-\frac{v_{g}{ }^{2} v_{f 1}}{v_{1}{ }^{2}}
$$

The expression for the function $\mathrm{Z}_{0}\left(\beta_{1}, \beta_{2}\right)$ for different ranges of values $\beta_{1}, \beta_{2}$ is presented in table 1 . The function $\mathrm{Z}_{0}\left(\beta_{1}, \beta_{2}\right)$ is linear with respect to the variable $\xi$, has an increasing section and a decreasing section. The inflexion point of the function determines the extreme value of the dynamic stress (Fig. 3).

Dynamic stresses $\mathrm{Z}_{0}\left(\beta_{1}, \beta_{2}\right)$ in the conveyor belt

\begin{tabular}{|l|l|c|c|c|c|c|}
\hline No & Вид функции $\mathrm{Z}_{0}\left(\beta_{1}, \beta_{2}\right)$ & $-2 \leq \beta<-1$ & $-1 \leq \beta<0$ & $0 \leq \beta<1$ & $1 \leq \beta<2$ & $2 \leq \beta<3$ \\
\hline 1 & $\mathrm{Z}_{0}\left(\beta_{1}, \beta_{2}\right)=v_{d} \tau_{n}(\xi-1)$ & & & $\beta_{1}, \beta_{2}$ & & \\
\hline 2 & $\mathrm{Z}_{0}\left(\beta_{1}, \beta_{2}\right)=v_{d} \xi\left(\tau_{n}-1 / v_{1}\right)$ & & $\beta_{2}$ & $\beta_{1}$ & & \\
\hline 3 & $\mathrm{Z}_{0}\left(\beta_{1}, \beta_{2}\right)=v_{d} \xi\left(\tau_{n}-1 / v_{1}\right)$ & & $\beta_{2}$ & & $\beta_{1}$ & \\
\hline 4 & $\mathrm{Z}_{0}\left(\beta_{1}, \beta_{2}\right)=v_{d} \xi\left(\tau_{n}-1 / v_{1}\right)$ & $\beta_{2}$ & & & $\beta_{1}$ & \\
\hline 5 & $\mathrm{Z}_{0}\left(\beta_{1}, \beta_{2}\right)=v_{d}\left(\tau_{n}-2 / v_{1}\right)(\xi-1)$ & $\beta_{2}$ & & & & $\beta_{1}$ \\
\hline 6 & $\mathrm{Z}_{0}\left(\beta_{1}, \beta_{2}\right)=v_{d}\left(\tau_{n}-2 / v_{1}\right)(\xi-1)$ & & $\beta_{2}$ & & $\beta_{1}$ \\
\hline 7 & $\mathrm{Z}_{0}\left(\beta_{1}, \beta_{2}\right)=v_{d} \tau_{n}(\xi-1)$ & & & $\beta_{2}$ & $\beta_{1}$ & \\
\hline
\end{tabular}




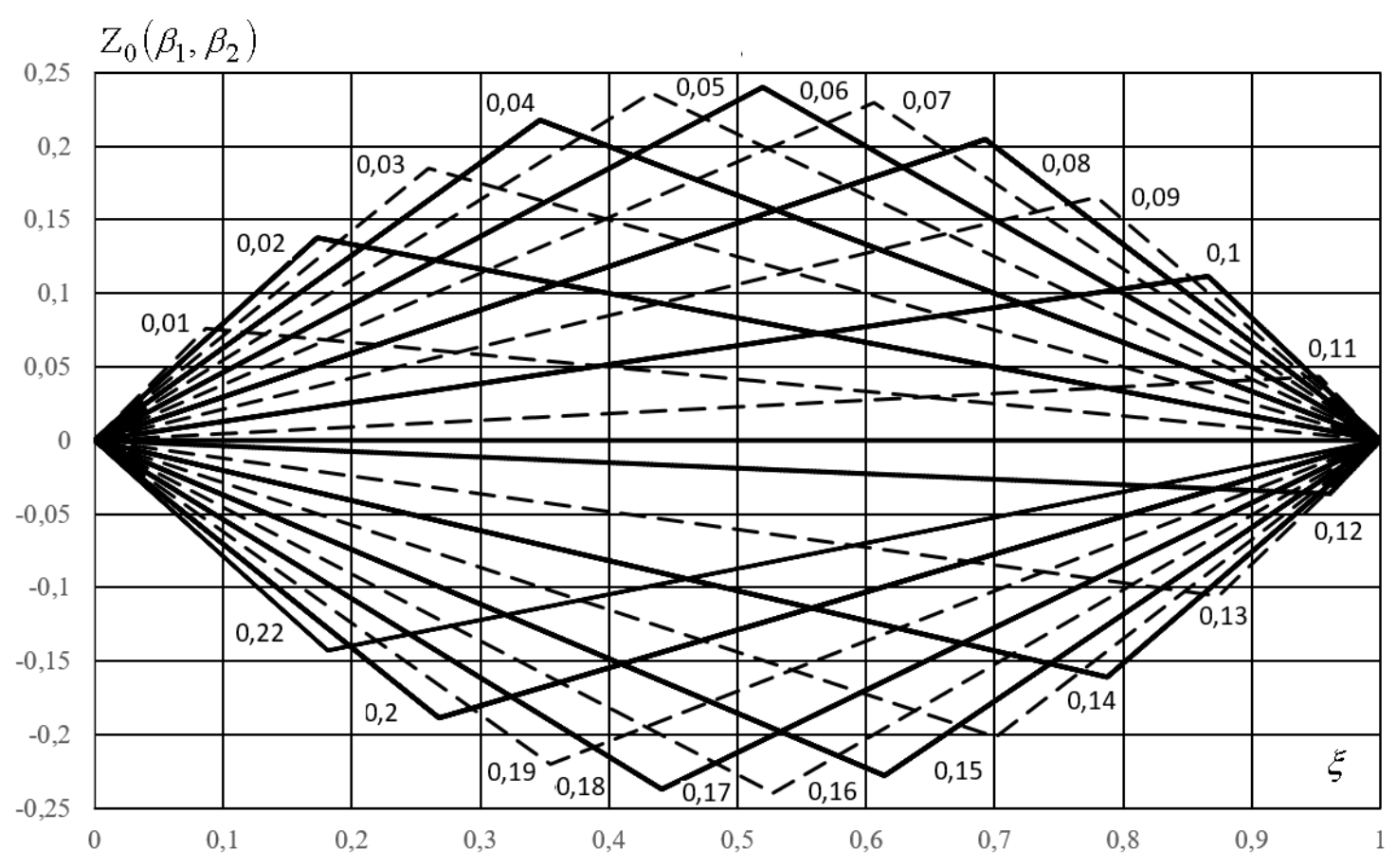

Fig. 3. Conveyor belt dynamic stresses $\mathrm{Z}_{0}\left(\beta_{1}, \beta_{2}\right)$ for times $\tau=0.01 \cdot m, m=0,1,2 \ldots$

Using (56), we determine the condition under which the value of the dynamic voltage is an insignificant part of the magnitude of the static voltage has the form

$$
\frac{v_{2}^{2}}{v_{1}^{2}} \xi+\left(\alpha_{1}-\frac{v_{2}^{2}}{v_{1}^{2}}\right) \approx \frac{v_{2}^{2}}{v_{1}^{2}} \xi>>\left|\frac{\mathrm{Z}\left(\xi+v_{1} \tau\right)-\mathrm{Z}\left(\xi-v_{1} \tau\right)}{2 v_{1}}\right| \approx\left|v_{d} \tau_{n} \xi\right| .
$$

This implies

$$
\frac{v_{f 1} \tau_{n}}{v_{f 0}+v_{b}}<<1
$$

Dynamic stresses do not affect the acceleration of the conveyor belt under the condition of a slow change in the value of the acceleration over a typical period of time $\tau_{n}$

$$
v_{f 1} \ll \frac{v_{f 0}+v_{b}}{\tau_{n}}
$$

\section{CONCLUSION}

Using the statistical method of modelling production systems in a two-moment description, a model of a conveyor transport system is presented. A feature of this model is the ability to take into account the effect of uneven distribution of material along the transport route on the propagation of emerging dynamic stress disturbances in the conveyor belt. The elastic properties of the conveyor belt are taken into account in accordance with the Hooke model. Calculation of resistances in the transport system is made in accordance with DIN 22101: 2002-08. The characteristic mode of operation of transport conveyor systems during acceleration of the conveyor section is considered in detail. In the approximation, when the conveyor system starts and the loading of the conveyor section is negligible, the conditions for the occurrence of dynamic stresses are determined. These expressions can be used to calculate the static and dynamic stresses of the conveyor belt.

\section{ORCID-IDs}

(D) Oleh M. Pihnastyi https://orcid.org/0000-0002-5424-9843, (1)Valery D. Khodusov https://orcid.org/0000-0003-1129-3462

\section{REFERENCES}

[1] N.A. Azarenkov, O.M. Pihnastyi and V.D. Khodusov, Reports of the National Academy of Sciences of Ukraine, 2, 29-35 (2011), http://dspace.nbuv.gov.ua/handle/123456789/37227.

[2] O.M. Pihnastyi, Problems of Atomic science and technology, 3, 322-325 (2007), http://dspace.nbuv.gov.ua/handle/123456789/111018.

[3] O.M. Pihnastyi, Belgorod State University Scientific Bulletin, 31(1), 147-157 (2014), https://ssrn.com/abstract=3404364. 
[4] O.M. Pihnastyi, Scientific bulletin of National Mining University, 4, 104-111 (2017), http://nbuv.gov.ua/UJRN/Nvngu_2017_4_18.

[5] N.A. Azarenkov, O.M. Pihnastyi and V.D. Khodusov, Reports of the National Academy of Sciences of Ukraine, 12, 36-43 (2014), https://doi.org/10.15407/dopovidi2014.12.036.

[6] D. He, Y. Pang, G. Lodewijks and X. Liu. Powder Technology, 327, 408-419 (2018), http://dx.doi.org/10.1016/j.powtec.2018.01.002

[7] T. Mathaba and X. Xia, Energies, 8(12), 13590-13608 (2015), https://doi.org/10.3390/en81212375.

[8] G. Yang, Sensors \& Transducers, 81(10), 210-218 (2014), https://www.sensorsportal.com/HTML/DIGEST/P 2492.htm.

[9] A.A. Reutov, in: IOP Conference Series: Earth and Environmental, 87, (2017), https://doi.org/10.1088/1755-1315/87/8/082041.

[10] I.A. Halepoto and S. Khaskheli, Indian Journal of Science and Techology, 9(47), 1-6 (2016), http://dx.doi.org/10.17485/ijst\%2F2016\%2Fv9i47\%2F108658.

[11] L. Ristic, M. Bebic and B. Jeftenic, Electronics, 17, 30-39 (2013). http://dx.doi.org/10.7251/ELS1317030R.

[12] L. Xinglei, Yu. Hongbin, in: Proceedings of the 3rd International Conference on Mechanical Engineering and Intelligent Systems (ICMEIS, 2015), pp. 789-793, https://doi.org/10.2991/icmeis-15.2015.148.

[13] E. Wolstenholm, Dynamica, 6(2), 25-35 (1980), https://www.systemdynamics.org/assets/dynamica/62/6.pdf.

[14] M. Andrejiova, D. Marasova, Acta Montanistica Slovaca, 18(2), 77-84 (2013), https://actamont.tuke.sk/pdf/2013/n2/2andrejiova.pdf.

[15] P. Markos and A. Dentsoras, FME Transactions, 46, P.313-319 (2018), https://scindeks-clanci.ceon.rs/data/pdf/14512092/2018/1451-20921803313M.pdf

[16] M. Bajda, R. Krol, Procedia Earth and Planetary Science, 15, 702-711 (2015), https://doi.org/10.1016/J.PROEPS.2015.08.098.

[17] A. Kumar and L.P. Singh, International journal of engineering sciences \& research technology system, 6(9), 337-341 (2017), http://www.ijesrt.com/issues\%20pdf\%20file/Archive-2017/September-2017/43.pdf

[18] V. Pasika, P. Koruniak, P. Nosko, O. Bashta and Yu. Tsibrii, Bulletin of NTU "KhPI": Series: New solutions in modern technologies. 45(1321), P.47-58 (2018). https://doi.org/10.20998/2413-4295.2018.45.07.

[19] Shirong Zhang, Xiaohua Xia, in: IEEE AFRICON-2009, (Nairobi, Kenya, 23-25 September 2009), pp. 17-27. https://doi.org/10.1109/AFRCON.2009.5308257.

[20] S. Gramblička, R. Kohár and M. Stopka, Procedia Engineering, 192, 259-264 (2017), https://doi.org/10.1016/j.proeng.2017.06.045.

[21] DIN 22101:2002-08. Continous conveyors. Belt conveyors for loose bulk materials. Basics for calculation and dimensioning. [Normenausschuss Bergbau (FABERG), DIN Deutsches Institut für Normung e.v. Normenausschuss Maschinenbau (NAM)], (2002), pp. 51.

[22] V.A. Budishevsky and A.A. Sulima, Theoretical foundations and calculations of transport of energy-intensive industries, (1999). pp. 216, http://ea.donntu.org:8080/jspui/handle/123456789/10466. (in Russian)

[23] M. Alspaugh, 2004, in: MINExpo-2004, (New York, Las Vegas, NV, USA, 2004), pp. 17-27, http://fliphtml5.com/pfyf/pccg/basic.

[24] B. Karolewski and P. Ligocki, Maintenance and reliability, 16(2), 179-187 (2014), http://yadda.icm.edu.pl/yadda/element/bwmeta1.element.baztech-ce355084-3e77-4e6b-b4b5-ff6131e77b30/c/karolewski_201402-02 en.pdf.

[25] H. Lauhoff, Bulk Solids Handling Publ. 25(6), 368-377 (2005), http://synergy-eng.com/pdf/BSH-2005_Beltspeed_Lauhoff.pdf.

[26] N.F. Timerbaev, A.R. Sadrtdinov, D.B. Prosvirnikov, A.A. Fomin and V.V. Stepanov, in: IOP Conf. Series: Earth and Environmental Science (IPDME 2017), 87, 1-9 (2017), https://doi.org/10.1088/1755-1315/87/8/082047.

[27] C.A. Wheeler, in: International Materials Handling Conference (Beltcon) 12, (Johannesburg, South Africa, 2003), pp.1-11. http://www.saimh.co.za/beltcon/beltcon12/paper1208.htm.

[28] Y. Lu and Q. Li, Measurement and Control, 52, 441-448 (2019), https://doi.org/10.1177/0020294019840723.

[29] A. Harrison, Bulk Solids Handling, 28(4), 242-247 (2008), https://static.wpe.au.syrahost.com/var/m_c/c1/c10/35361/296385bsh2008_non-linear_dynamics.pdf?download.

[30] A. Semenchenko, M. Stadnik, P. Belitsky, D. Semenchenko and O. Stepanen, Eastern-European Journal of Enterprise Technologies, 4/1, 42-51 (2019), https://doi.org/10.15587/1729-4061.2016.75936.

[31] V.V. Degtjarev, Нормирование топливно-энергетических ресурсов и регулирование режимов энергопотребления [Rationing of fuel and energy resources and regulation of energy consumption modes], (Nedra, Moscow, 1983), pp. 225, http://www.xn--80affsqimk15h.xn--p1ai/_ld/7/735__-pdf. (in Russian)

[32] O.M. Pihnastyi, Scientific bulletin of National Mining University, 6, 44-51 (2019).

[33] J. Antoniak, Transport Problems, 5(4), 5-14 (2010), http://transportproblems.polsl.pl/pl/Archiwum/2010/zeszyt4/2010t5z4_01.pdf.

[34] O.M. Pihnastyi and V.D. Khodusov, Bulletin of the South Ural State University. Ser. Mathematical Modelling, Programming \& Computer Software (Bulletin SUSUMMCS), 10, 67-77 (2017), https://doi.org/10.14529/mmp170407.

[35] O.M. Pihnastyi. Statistical theory of production systems, (Kharkiv: KhNU, 2007), pp. 388.

[36] R. Pascual, V. Meruane and G. Barrientos, in: Proceedings of the XXVI Iberian Latin-American Congress on Computational Methods in Engineering CILAMCE 2005 (CILAMCE-2005, Santo, Brazil, 2005), Paper CIL0620, $\mathrm{http} / /$ citeseerx.ist.psu.edu/viewdoc/download?doi=10.1.1.494.34\&rep=rep1\&type=pdf.

[37] A.O. Spivakovsky and V.A. Dyachkov, Транспортныле машины [Transporting machines], (Mechanical Engineering, Moscow, 1983), pp. 487. (in Russian)

\section{ГІДРОДИНАМІЧНА МОДЕЛЬ ТРАНСПОРТНОЇ СИСТЕМИ}

\section{О.М. Пигнастий ${ }^{\mathrm{a}}$ В.Д. Ходусов}

${ }^{a}$ Національний технічний університет «ХПI», 61002

Україна, м.Харків, вул. Кирпичева, 2

${ }^{b}$ Харківський начіональний університет імені В.Н. Каразіна

61022, Украӥна, Харків, пл. Свободи, 4

Розглянуто гідродинамічна модель виробничих систем з потоковим методом організації виробництва. Визначено основні макропараметри стану виробничої потокової лінії і взаємозв'язку між ними. Обгрунтовано вибір багатомоментного наближення для моделювання виробничої потокової лінії. Показано, що конвеєр конвеєрного типу це складна динамічна система з розподіленими параметрами. Сформульовано крайову задачу про поздовжні коливання конвеєрної стрічки при 
русі матеріалу по маршруту транспортування. Передбачається, що ковзання матеріалу уздовж конвеєрної стрічки відсутня, а деформація, що виникає в конвеєрній стрічці пропорційна доданої силі (модель пружних деформацій Гука). Показано суттєвий вплив нерівномірності розподіл матеріалу уздовж маршруту транспортування на швидкість поширення динамічних напружень в конвеєрній стрічці. При побудові граничних і початкових умов використані рекомендації DIN 22101: 2002-08. Досліджено механізм виникнення поздовжніх коливань конвеєрної стрічки при русі матеріалу по маршруту транспортування. Визначено основні параметри моделі, які $є$ причиною виникнення динамічних напружень. Показано, що динамічні напруги формуються в результаті суперпозиції напружень в прямій і відбитої хвилі. Записані аналітичні вирази, що дозволяють розрахувати величину динамічних напружень в конвеєрній стрічці і визначені умови виникнення руйнувань конвеєрної стрічки. Розглянуто характерні фази початкового руху матеріалу по технологічному маршруту. Досліджено процес виникнення динамічних напружень при постійному і змінному прискоренні конвеєрної стрічки. Представлена динаміка поширення напруг уздовж маршруту транспортування. Показано, що величина динамічних напружень може перевищувати гранично допустиме значення, що призводить до руйнування конвесрної стрічки або конструктивних елементів. Зроблено оцінку тривалості перехідного періоду, яка потрібна для забезпечення безаварійного режиму функціонування транспортної при прискоренні або гальмуванні конвеєрної стрічки. Використання безрозмірних параметрів дозволяє сформулювати критерії подібності транспортних систем конвеєрного типу.

КЛЮЧОВІ СЛОВА: гідродинамічна модель транспортної системи, двох-моментний опис виробництва, модель Гука, балансові рівняння, PDE-модель виробництва

\section{ГИДРОДИНАМИЧЕСКАЯ МОДЕЛЬ ТРАНСПОРТНОЙ СИСТЕМЫ \\ О.М. Пигнастый ${ }^{\mathrm{a}}$, В.Д. Ходусов \\ ${ }^{a}$ Национальный технический университет «ХПИ» \\ 61002, Украина, г. Харьков, ул. Кирпичева, 2 \\ ${ }^{b}$ Харьковский национальный университет имени В.Н. Каразина 61022, Украина, Харьков, пл. Свободы, 4}

Рассмотрена гидродинамическая модель производственных систем с поточным методом организации производства. Определены основные макропараметры состояния производственной поточной линии и взаимосвязи между ними. Обоснован выбор много моментного приближения для моделирования производственной поточной линии. Показано, что поточная линия конвейерного типа - это сложная динамическая система с распределенными параметрами. Сформулирована краевая задача о продольных колебаниях конвейерной ленты при движении материала по маршруту транспортировки. Предполагается, что скольжение материала вдоль конвейерной ленты отсутствует, а деформация, возникающая в конвейерной ленте пропорциональна приложенной силе (модель упругих деформаций Гука). Показано существенное влияние неравномерности распределение материала вдоль маршрута транспортировки на скорость распространения динамических напряжений в конвейерной ленте. При построении граничных и начальных условий использованы рекомендации DIN 22101:2002-08. Исследован механизм возникновения продольных колебаний конвейерной ленты при движении материала по маршруту транспортировки. Определены основные параметры модели, которые являются причиной возникновения динамических напряжений. Показано, что динамические напряжения формируются в результате суперпозиции напряжений в прямой и отраженной волны. Записаны аналитические выражения, позволяющие рассчитать величину динамических напряжений в конвейерной ленте и определены условия возникновения разрушений конвейерной ленты. Рассмотрены характерные фазы начального движения материала по технологическому маршруту. Исследован процесс возникновения динамических напряжений при постоянном и переменном ускорении конвейерной ленты. Представлена динамика распространения напряжений вдоль маршрута транспортировки. Показано, что величина динамических напряжений может превышать предельно допустимое значение, что приводит к разрушению конвейерной ленты или конструктивных элементов. Произведена оценка продолжительности переходного периода, которая требуется для обеспечения безаварийного режима функционирования транспортной при ускорение (торможение) конвейерной ленты. Использование безразмерных параметров позволяет сформулировать критерии подобия транспортных систем конвейерного.

КЛЮЧЕВЫЕ СЛОВА: гидродинамическая модель транспортной системы, двух моментное описание производства, модель Гука, балансовые уравнения, РDE-модель производства 